\title{
The Artistic Display, Performance and Management Qualities of Nollywood Actors and Actresses: Implication for Professionalism in the Performing Arts Industry
}

\author{
Israel W. Udomisor, Opara S. Anayo \\ Department of Mass Communication, University of Maiduguri, Maiduguri, Nigeria \\ Email: iriswilson2012@yahoo.com
}

Received 8 January 2014; revised 19 February 2014; accepted 27 February 2014

Copyright (C) 2014 by authors and Scientific Research Publishing Inc.

This work is licensed under the Creative Commons Attribution International License (CC BY).

http://creativecommons.org/licenses/by/4.0/

\section{(c) (i) Open Access}

\begin{abstract}
The artistic presentation of Nigerian actors and actresses is gaining better acclaim and recognition across the film industry both in Nigeria and Africa. Nollywood films are recognised because of their creative performance in the film industry when compared with the performance of other film industries in Africa. The continuous exposure of Nollywood actors and actresses to prominent actors and actresses from across the world especially Hollywood and Bollywood film industries has helped actors and actresses in Nollywood to diversify their artistic qualities professionally. Despite Nollywood success flanked by Nigerians actor and actress in home videos and across films produced in Africa more has to be done in terms of production, film content, quality and originality. Today Nollywood as a film industry with highly rated actors and actresses are seen as a platform for modelling the future and prospect of film making in Africa especially as the youths are seeking to make career in the performing art industry. As such, Nollywood will continue to be a point of reference for other African film makers and industries on the continent when seeking for artistic display and performances.
\end{abstract}

\section{Keywords}

Nollywood; Artistic Display; Performing Arts; Professionalism 


\section{Introduction}

The presence of Nollywood on the podium of Nigeria and beyond her shores shall continue to be appraised and applauded through the dynamic factors and changes that have seen Nollywood, a film industry contending among other big and well established film industries of the world who are taking all the accolades as a result of their tremendous growths, level of technology, professionalism, film revenue generation, and other means of film production that appeal to their numerous viewers.

The rapid growth and development of any society lies on the gains of being informed, educated and entertained. These functions are constantly played by Nollywood within the context of films produced on different issues such as social vices, poverty, family, politics, love, community rivalry and corruption among other widespread issues ravaging the Nigerian society. These films stared well known Nollywood actors and actresses with the likes of Pete Edochie, Richard Mofe Damijo, Nkem Owoh, Ramsey Noah, Desmond Elliot, Emeka Ike, Genevieve Nnaji, Omotola Jakande, Ini Edo, Mercy Johnson, Rita Dominic and Ngozi Nwoso among others.

Nollywood is considered to be the empire for films in Africa by film lovers in most African cities, especially; West, East and Southern Africa who are fascinated with the kind of African, Asian and Western styled films produced by Nollywood. For this reasons, Nollywood film industry is earmarked and considered as the film destination and hub for actors and actresses, directors and producers on the continent of Africa.

Adjudged as the third best producing and producers of films in the world, Pierre (2008: p. 43) observed that "if Nigerian films were only popular in Nigeria then the phenomenon could have been put to a particular local fascination, something larger than life from a country that is larger than life." Pierre continued with the opinion that, "Nigerian films have been an impressive success right across Africa."

The spotlights accorded Nollywood films since its emergence from the last two decades are overwhelming. Such perspective has given rise to Nollywood film industry as a force already reckoned with in Africa. Oladunjoye (2008) observed that in the past, as a Nigerian, if you travel abroad people would ask if you had brought food and spices from home, but today they ask if you have brought any Nigerian film.

Without doubt, the high regards and continuous acumen attached to Nigerian film industry Nollywood would in some ways be compared to Hollywood films in America and Bollywood films in India in terms of popularity, demand and audience viewership. These efforts have been made more encouraging by the performance of the various actors and actresses who in their own strides, try to create a niche and to some extent personality cult as the case maybe because of their popularity with the growing audience or fan based within Africa.

Nollywood, like other film industries such as Hollywood and Bollywood found around the world has risen through the contributions implored by her artistic displays and outstanding qualities in terms of the performance of its actors and actresses in film productions. These varying performances and displays accord the industry an elevation within the arena of film festivals and viewership such as the Durban International Film Festival, Berlin International Film Festival, British Urban Film Festival, Cannes Film Festival, London Film Festival, and Hollywood Film Festival among others.

This research therefore assesses "The Artistic Display, Performance and Management Qualities of Nollywood Actors and Actresses with its Implications for professionalism in the Performing Arts Industry.”

\subsection{Aims and Objectives}

The aims of this research were;

1) To appraise Nollywood contributions in the film industry in Africa;

2) To examine the artistic performance of some Nollywood actors and actresses in the performing art industry;

3) To examine the impact of professionalism in Nollywood film industry.

\subsection{Theoretical Framework}

Social learning theory was adopted for the research. The reason for the theory is based on the assumption that "people can learn new information and behaviour by simply watching other people". Social Learning theory proposed by Albert Bandura in 1977 is equally known as Observational Learning or Modelling which can be used to explain a wide variety of behaviours.

Social Learning theory is built on three main factors which are: 
1) The idea that people can learn through observation;

2) The idea that internal mental states are essential part of this process;

3) The theory does not mean it will result in a change in behaviour.

Films are produced in line with the theory to help individuals in the society who view these films starring role models and professional actors and actresses of their choice learning and internalising certain qualities and attribute from them which eventually can affect their attitude leading to a change of behaviour and life style.

Observational Learning theory demonstrates that people can learn new information without exhibiting new behaviour. In line with Bandura's ideas films that we watch to seek information do not necessary need to affect our mind-set or attitudes toward other needs. A lot could be said to have moulded individual's behaviour from what they see or are presented in films they watch. It is however imperative to note that the performance quailties displayed by various actors and actresses enable viewers to learn some important aspect of life in the society they belong.

\section{Literature Review}

\section{An overview of film history in Nigeria}

Former Soviet Leader Lenin Vladimir (1958) referred to film "as the most important of all the arts for the construction of socialism". In line with Lenin's thoughts of what film could mean, another scholar in the area of films; Christopher (2008: p. 19), noted that: "films are said to be nothing more but moving pictures in 'motion' which are series of slightly different captured still pictures or scenes passing before the viewer in fascinating but sequential order, and at a regular specified speed to tell a story."

Films in this perspective are known as optical illusion which Opubor et al. (1979: p. I) are of the opinion that "of all the media of mass communication, the motion picture (film) has perhaps the most universal appeal and impact."

Properly conceived and executed, a film can rise above the limitations of language and cultural barriers by the powers of the visual images; its use of music and sound effects can succeed in conveying the intended messages to viewers of a heterogeneous background.

\subsection{The Era of Film Production in Nigeria}

The first film in Nigeria was exhibited in August 1903 at the Clover Memorial Hall in Lagos. Films as a medium, was still new in those days and was still technically in its infancy. However, the content then was largely documentary based on English cultures depicting some forms of superiority among other cultures such as French, Portuguese, Spanish, Indians and Africans. According to Asobele (2003) "our colonial masters exhibited films that presented their culture, and their superiority. The colonial masters imported films to propagate their interests, and give a make believe that portrays their rule and authority as the best."

The first film shown according to the Lagos Standard "included scenes of a steamer moving through water, a conjugal dispute, a steeplechase, acrobats and other pictures shown with the vividness of life, and scenes of coronation of King Edward VII at Westminster Abbey".

Film shown in Nigeria, took a different dimension during World War II. The widespread use of film by the British Government in its wartime propaganda became well accounted for, while mobile Cinema vans operating in the open air travelled all over Nigeria bringing the war news of the success of the Allies and the defeat of the Germans to the Nigerian populace. However, the most popular films were the one that starred British Charlie Spencer Chaplin who intimated Cinema greats of his time.

In 1947, a Federal Film Unit (FFU) was established with the mandate to take over from the Colonial Film Unit (CFU). Although film production was not really encouraged, the colonial office of information made sure that documentaries produced by the Post Office Film Unit (POFU) in London was given sufficient distribution through the British Council and such other bodies as the Church Missionary Society (CMS) in Nigeria.

In 1962 the emergence of the first Nigerian Film Company (NFC) known as Latola Films (LF) helped set Nigerian film industry rolling into more formidable heights. Latola Film (LF) was registered four years later in 1966. The delay in registration helped his company to prepare for the task at hand and proper projection of films that were made in Nigeria in later years to come.

According to Opubor et al. (1979: p. 8) "Latola films undertook the production of documentary films and newsreels mainly for foreign agencies. Later on, in Nigerian school premises, village halls, open spaces, cano- 
pies, civic centres, even shades provided by big trees were used as adequate theatres for exhibition of films.”

The production of indigenous films in the 1970's such as Kongi Harvest by Calpoly Nigerian Films (CNF) and Bullfrog in the Sun an adaption of Chinua Achebe's novel: "Things Fall Apart" and "No Longer at Ease" marked the birth of home video which through the valgaries of the society gained popular acceptance in virtually every home, especially in the Southern, Eastern, Western and parts of Central states of Nigeria.

The entry of film popularly known as "Home video" into the entertainment industry as it is commonly known in the late 80s marked a new chapter of films produced in Nigeria. Ritchard and Olufemi (2008: p. 64) observed that "the entertainment industry was seen as an inferior but welcomed substitute to celluloid as it was received with mixed feelings of satisfaction and anxiety." Satisfaction because it had given to Nigerians what neither Hollywood nor Bollywood could give. Subsequently, it was believed that foreign movies were responsible for the increasing waves of immorality among the youths which include: the use of drugs, brain drain, indiscriminate sex, alcoholism, homosexuality, lesbianism among other harmful practices which have eroded our societal norms and values.

\subsection{Categories or Types of Films}

Films are basically categories into three major groups which include: Non-fiction (documentary films) fiction (feature films) and Animation.

\subsubsection{Non-Fiction (Documentary Films)}

Documentary films are as old as cinematography. As the name suggests, these are factual works of art which are sometimes referred to as Cinema. Various earliest documentary film makers include Thomas Edison and The Lumiere Brothers.

Documentary films are used to make pertinent statements, and also to keep records of important and remarkable events for future generation. Films in this category include the following: Inviticus, Pearl Harbour, Coach Carter, Gifted Hands, and The Debaters among others.

\subsubsection{Fiction (Feature) Films}

Fiction films are the opposite of documentary films, with narrative structures exploring different plots patterns. Feature films task the creative and artistic ability of the scriptwriter or film-maker in creating an interesting story which is a major determinant of film appeals to its audience.

Feature films involve elaborate acting, costume make-up and other creative effect geared at creating a film that is similar to the real world events.

Feature films are usually "full-length" motion pictures which are more than 60 minutes in durations, but within the prescient of 90-120 minutes and on one particular topic. They include; X-Men, Harry Potter, Twilight, Men in Black among others.

\subsubsection{Animation}

Animated films are those in which characters in scenes through individual drawings and paintings, or illustration are photographed frame by frame (stop-frame cinematography).

The earliest cinema animation was composed of frame-by-frame, hand drawn images.

These two-dimensional static arts come alive when combined with movement, created and imaginative cinematic images; animals and other inanimate objects could become evil villains or heroes.

Animation generally appeal to children, but that is not to say adults do not also find them appealing. Some example include: Alice in Wonderland, Peter Pan, Aladdin, The Lion King, Shrek, Kunfu Panda, Ice Age, Tom and Jerry and a host of others. Other film categories of film genres includes, Action Films, Adventure films, War films, Comedy films, Western films, Epic films, Science fiction, Horror films, Crime and Gangster films, Drama films, Musical and Dance films.

\subsection{The Emergence of Nollywood Film Indutry in Nigeria}

Nigeria portrays a dynamic and diverse culture enriched with traditional values and beliefs which is showcased to the world via artistic performance and presentations. However, the advent and development of motion pictures production gave rise to the present day Nollywood derived from Hollywood in the same manner as Bolly- 
wood which is an offshoot of Home video films.

According to www.nollywoodmovies.com; Nollywood is the nickname of the brand of Nigerian film making that exploded in the early nineties precisely (1992) with the ground breaking film titled (LIVING IN BONDAGE) produced in Igbo language and subtitled in English, by Kenneth Nnebue of NEK Video Links with production in Eastern city of Onitsha. This film unarguably set the stage for what Nollywood has become today.

The first Nollywood films were produced with traditional analog video such as Betacam SP, but today almost all Nollywood films are produced using digital video technology. Nollywood overtime exploded into a booming industry that pushed foreign media off the shelves, an industry now marketed all over Africa and the rest of the world.

In 2009, Nollywood was described by UNESCO as the second biggest film industry in the world after Bollywood in terms of output and called for greater support for the industry which is the second largest employer of labour in Nigeria. Besides Nollywood there exist Kannywood, promoters of films produced in Hausa language found in the Northern part of Nigeria (Kano).

\subsubsection{Nollywood and Other Film Industries}

Films take different approaches with different audiences young and old as thoughtfully designed by the intending storyline. However, these films are in no way compared to films produced by film industries of advanced nations outside the continent of Africa such as Hollywood and Bollywood.

Films produced in Nollywood would be analysed under the following areas: artistic display, performances, themes, quality of production, level of direction, aesthetic presentation and effect or impact on viewers.

\subsubsection{Artistic Display}

A Film cannot be accepted by the publics or viewers if the scenes set in motion are of poor presentation. It is therefore important that in the production of films, the artistic displays performed by various actors/actress perform their roles properly as well groomed professionals. The act displayed by film casts in any production is vital. The essence is that films are better suited by viewers when artistic displays shown by actors and actresses are of genuine standards.

Good artistic display is the pillar on which films produced can be applauded, and the varying cast praised upon. However it is vital that films with well outstanding performance especially in Nollywood should be able to have; interpretable roles, good transcending scenes, a balance of professionalism from cast present in the film, directing, visual effects, and sound qualities among others. Example: Ije, Private Storm, White Waters.

\subsubsection{Performances}

Films produced in Nollywood, Bollywood or Hollywood intends to have the best of actors and actresses performances. The professional performances displayed by various cast help the personalities of actors and actresses to grow among film viewers in subsequent films produced.

However, the three major film industries known in Nigeria by esteemed viewers include; (Bollywood, Hollywood and Nollywood). Although the performance showcased by Nollywood Actors/actresses in films still needs more professional impetus when compared to actors and actresses found in Bollywood and Hollywood as the case maybe.

\subsubsection{Themes}

What makes a film interesting and captivating is the theme implored. As important as themes may be, they are seldom the case in some Nollywood films. Little considerations have been put into creating original themes among Nollywood producers which as a result see producers in Nollywood industry dwell on foreign themes as a means of selling their products to the viewers. Felix and Cecilia (2008) note that "Nigeria home video themes have over the years captured popular criticism and audience interest.”

The themes common to most Nollywood films cover areas like greed/avarices, impatience, jealousy, envy, pride, love and hate.

\subsubsection{Quality of Production}

One major problem faced by Nollywood is in the area of production. Production of films are substandard in terms of picture quality, sound quality, and lighting, maturity of cast, scene change, action and graphical effect. This development in quality suffered in Nollywood films subject viewers to seek for films with better organisa- 
tion and coherence. For Example: Blackberry Babes compared to Mean Girls 2.

The storyline for Blackberry Babes is poor, and in a bid to see the characters get into the film roles outlined makes the character of the cast look very unprofessional. Mean Girls saw the overzealous and superfluous act characterised in most Nollywood acts. No form of moral could be established in the film, and the film does not portray any form of educating its viewers.

\subsubsection{Level of Directing}

Directing by Nollywood film directors is nothing of professional standards as compared to Hollywood and Bollywood directors who put in so much effort into the nature and outcome of films they direct. However, there is tremendous improvement from some directors who take some professional designed courses in the art of directing in internationally acclaimed film industries. For example in Family Ties (Nollywood), and Friends (Hollywood) the level of directing put into the production of Friends cannot be compared with that of Family Ties. The reason is that the professionalism in directing put into Friends supersedes that of Hills and Valleys. Directors such as Lancelot Oduwa, Amaka Igwe, Peter Igho, Chico Ejiro, and Francis Duru cannot be equalled to the likes of Bruce Willie, Brad Pitts, and Steven Spielberg.

\subsubsection{Aesthetic Presentation}

The use of scene, graphic and other film effects is important. The aesthetic presentation in films enables various intending messages and actions to be passed to the viewers. This however does not project well in Nollywood films. Hills and Valleys by Common Grounds Productions Company lack in the usages of aesthetic presentation when compared to Friends produced by Bright, Kauffman, Crane productions.

\subsection{Nollywood and Other Film Industries in Africa}

Nollywood's activities in Africa's film industries are highly appreciated in terms of what is obtainable as compared to other parts of Africa such as Ghana with Ananse film and South Africa with Boyana films. However, at its pace to meet other global industries, Nollywood faces some forms of support and criticism by a host of film analysts who through their observations are moving and projecting Nollywood forward.

While appraising Nollywood's landmark among films in Africa, journalists and writers such as; Helen Muchimba describes the impacts of Nigeria films in Zambia as "The stories tend to be quite simple but very dramatic and heavy on the emotions. The women wail and are avaricious, the men are just as emotional and very vengeful. Throw in a gibbering bone-rattling juju man, bible-waving preacher and what you have is a brew of conflict, revenge, trials and tribulations. The likes of which are keeping Zambians, especially in the capital city, Lusaka glued to TV screens for hours on end..." Such led the mother of one family member to complain that "the children had started talking like Nigerians". You hear them say "Yes-O" and "No-O" and at every possible opportunity they say "God forbid".

Pierre (2008) observed that; Jahman Anikulapo a journalist visiting Cote'd'Ivoire was told by his guide, Ramon that films sold in his country (Cote'divoire) are mostly Nigerian films and a few from Ghana ...Pete Edochie, Liz Benson, Richard Mofe-Damijo, Bimbo Akintola are all very popular in his country.

Not only are Nigerian films allowed into Anglophone African countries, Nigerian films are aired on television without any subtitles in at least seven francophone countries of Niger, Togo, Senegal, Cameroun, Democratic Republic of Congo, and Burkina Faso. While in Benin, Yoruba films are massive hit, not just in video clubs but in cinemas.

Nollywood has risen to a notable standard that has led virtually all parts of the society (young and old) to fall in love with Nigeria made films from Nollywood. Pierre (2008: p. 43) observed that "if Nigeria films were only popular in Nigeria, then the phenomenon could have been put down to a particular local fascination something larger than life from country that is larger than life, but the films have been an impressive success right across Africa.” They are found in video cassette or on VCD in the markets of nearly all Anglophone countries, and hardly a day pass when there isn't a Nigerian film on one of its television channels.

\subsection{Nollywood Films and Other Films Produced in Africa}

Films shown by Nollywood are an indication that Nigerian film supersedes films produced from other African countries. Looking at the level of Nollywood's film content in the area of artistic display goes to show that the 
production of films in the present era tries as much as possible to meet the expectations of esteemed viewers in terms of quality, contents, storylines and scenes display. It is important to note that some of the films produced in countries like; Ghana, Zambia, Angola and Benin Republic are nothing really to write home about in as much as they try to reflect issues happening in their own settings.

For instance, a film like "Private Storm" by Vivian Ejike shows the depth of production and casts being natural in their roles, good graphical work and scene changes. But when you look at a Ghanaian movie titled "The Game”, all that represents the film; the cast, directing, production quality, graphics and action; shows a very poor quality put in by the producers and directors of the film.

African films, most especially Ghanaian films show high rate of indecency which in no way represents the African way of life. These growing immoralities such as nudity, kissing, caressing and romance among other immoral depictions represent a not too African ideal in film settings.

Nollywood films however represent in so many aspects issues that are prone to a country like Nigeria. Such as: fraud, corruption, power play, crimes, ritual killings, blood money, kidnappings, caste relationship, social income class statues, slavery and royal affection.

Nollywood film industry is recognized when compared to other films industries in Africa because of the following reasons. It is clearly seen that Nollywood films draw their strength from many cultural influences both domestic and foreign, while it remains fundamental distinctive. In terms of personnel, production techniques, administrative structure and narrative elements, Nollywood is not sharing a similar value with foreign tradition (Udomisor, 2012). The Nigerian film industry, it is noted, is defined and sustained by Nigerians.

While this is so, Udomisor et al. (2012) clearly point out that the thematic and aesthetic choices of Nollywood are determined to a large extent by the preferences of its audience and therefore attract broad appeals across Africa. To the Nigerian film makers, Nigeria and Africa are the narrative entities and their films are the agents in this narrative act.

Nollywood films gain such a wide recognition in Africa compared to other film industries in the continent because Nollywood films act as stabilizing forces, emphasizing the collective mentality of a typical African, Nigeria inclusive by educating them along certain established lines which according to Udomisor et al. (2012) helps to ensure the development of collective memories of the past, helping them to maintain a distance from the frightening present and project life into the future.

It is well known that film as a strong medium of communication displays a range of ethical and cultural positions. Nigerian film makers in Nollywood consciously and forcefully portray these in their films which lead to the transformational needs of Nigerians and Africans offered through the aesthetic possibilities of film technology.

Although there has been some criticism of the Nigerians films on recurrent themes such as witchcraft and proliferation of black magic, Udomisor et al (2012) say that it is true that these themes have their root in popular cosmology.

Nollywood films are recognized when compared with other African films because Nollywood films have come to assume an authority over the values of people lives not only in Nigeria but in the entire African continent, such that what people see is them are taken not just as functional projection of imaginative consciousness but as the true, authentic mirror of what the society is, a veritable market of what the society represents and much worse, of the ideal that it aspires or must aspire towards.

\subsection{Nollywood Films and Global Film Industries}

Nollywood emergence on the spotlight of film making and production indicated an end to the cultural dominance (imperialism) of western films. For long Hollywood of the U.S.A and Bollywood of India, according to Segun (2008: p. 301) "are but clear manifestation of the impact of modern technology on film production in the phenomenon of Nollywood".

Growth of Nollywood is as a result of borrowed ideas from Hollywood and Bollywood who had already excelled in film making, production, distribution, and high sale records.

The influence of Chinese films have also contributed to Nollywood production (karate and martial art scenes), including the Americanisation influence on Nollywood films in terms of language usage (accent), behaviour, dressing and scene usage and at times, Nollywood films have the same title with Hollywood films. These includes; Most Wanted, Rush Hour, Desperate Housewives, Two Can Play the Game, Passion of Christ, Angels and Demons, among others. 
Nollywood through the success built on other foreign film industries (Hollywood, Dollywood and Bollywood) is working endlessly to improve in its production quality, script writing, dressing and use of modern technological equipments in her film production.

\section{Nollywood Actors and Actresses versus Actors and Actesses of Other Film Industires}

The roles played by actors and actresses in films are reflections of the storylines way of passing a message to the viewers. Actors and actresses all over the world try as much as possible to live up to the characters (antagonist, protagonist, flat character or cameo roles). In Nigeria such situations are of no exceptions.

Nollywood as a film industry has seen the rise to stardom of some actors and actresses who today can perform if opportune to work alongside those in Hollywood or Bollywood.

Therefore, it is important to highlight and compare the performance qualities of Nollywood actors and actresses to those of Hollywood and Bollywood film industries thereby comparing and analysing some actors and actresses of these industries.

\subsection{Hollywood}

JULIA ROBERTS-Became a sensational after making the headlines in the film industry of Hollywood in the film "Pretty Woman” which she starred alongside Richard Gere in 1990. Julia Robert is among a few film greats that started a career in acting via attending an acting school during her early years in life. Her rise among Hollywood greats not only among the female actresses, but equally among her male counterparts shows her character as an outstanding performer who has graced many high profile films such as Erin Brockovich, Steel Magnolias, My Best Friend's Wedding, Runaway Bride, Valentine’s Day and Mirror Mirror among other epic blockbusters.

Richard Tiffany Gere-Is an American actor. He began acting in the 1970's while playing supporting role in the film titled "Looking for Mr. Goodbar" Gere came into prominence in 1980 for his role in the film "American Gigolo" which established him as a leading man and a sex symbol, and later "Pretty Women" in 1990.

Richard Gere is considered among the finest Hollywood film actors whose style and performance of four decades has taken him via film production and location to different parts of the world. His performance drive in films such as "An Officer, Primal Fear, and Chicago" won him a Golden Globe among other film he has starred.

William Bradley-Popularly known as BRAD PITT is said to be one of Hollywood's finest actors cum producer. Brad Pitt has received four Academy Award Nominations and five Golden Globe Award nominations, while winning one Golden Globe. Pitt gained recognition as a cowboy hitchhiker in the road film Thelma \& Louise, while his first leading role in "A River Runs through It" gave him that impetus as one of Hollywood finest actors.

Other films by Pitt include: 12 Monkeys, The Curious Case of Benjamin Button, Moneyball, Legends of the Fall and Oceans Elevens and its sequels, Oceans Twelve and Ocean Thirteen among other great and mind thrilling films.

Nichole Kidman-Kidman who is of Australian origin began her film career in 1983. Her breakthrough in the 1989 thriller "Dead Calm" gave her recognition, helping her earned worldwide recognition for performances in "Days of Thunder, Far and Away and Batman Forever".

Nichole Kidman is an exceptional Hollywood actress whose drive in the film industry continues to grow her experience as a professional performer.

\subsection{Bollywood}

AISHWARYA RAI-Rai is a top Indian actress whose artistic qualities in Bollywood film industry are applauded by her contemporaries. Her level of interpreting roles and performing said roles has seen her rise as one of the best and few Indian women who is regarded as a professional film casts. She has carved a niche for herself in acting both in Bollywood and Hollywood.

Her acting and performance qualities show that Bollywood as a film industry has improved and developed technologically from what used to be known in the past as an upcoming film industry. Aishwarya as an actress has proven to be a brilliant and genuine actress with her performances in "The Duo", "Aur Pyaar Ho Gaya, Taal" among other major films and prestigious film projects. 
Aamir Khan-Aamir Khan was first introduced as a child artiste in the 1970's hit "Yaadon Ki Baaraat". He is seen as the complete Indian actor as a result of his fitting in all genres of Indian films namely; action, drama, comedy and romance. Aamir Khan is regarded as a complete Indian actor of the post 1990 generation of actors for his diverse choice of roles and films such as; "3 idiots, Like Stars on Earth, Rang De Basanti, Lagaan", amongst others.

Sharman Joshi-Is an Indian actor whose performance in some series of Bollywood films has shown his dynamism and professional quality as an outstanding actor. Films like "Range De Basanti, Golmaal and 3 Idiots" have all but among other films earned him international acclaims in the film industry and among viewers.

As an Indian film and theatre actor, Sherman Joshi has worked on various stage productions in English, Hindi, Marati and Gugarati languages.

Kareena Kapoor-Kapoor is but a few film personalities who were born into a family of personnel's. Her paternal great grandfather Prithviraj Kapoor and grandfather Raj Kapoor, her paternal uncles. Shammi, Shashi and Rishi, as well as aunts. Neetu Singh, and Jennifer Kendal, the wives of Rishi and Shashi respectively. From her maternal side, her grandfather Hari Shivdasani, and aunt Sadhana have been actors in their own rights.

Kapoor's ability to interpret roles makes her one of the few most sought-after actresses in Bollywood. Her debut film "Refugee" set the stage for her other film appearances such as "Chameli, Dev, Omkara, Lajjo" amongst others.

\subsection{Impact of Professionalism in Nollywood Films to the Performing Arts}

Films cannot be relevant to the viewers if the different performances displayed by actors and actresses in the various scenes making up the production of a particular film are not effective or conform to the ideas intended. The importance attached to any good performance in acting gives the production of a particular film or films produced that needed acceptance and appraisals from the viewers.

It is important to note that viewers are virtually interested and captivated with the performances presented by actors and actresses in films they watch. With Nollywood actors and actresses being natural to the various parts the play or contribute in a film, viewers will no doubt appreciate their roles to the growth of Nollywood film industry.

Therefore, professionalism is fundamental when dealing with any form of career or occupational choice. The aspect of professionalism elevates the performances of those involved and harnesses their potentials. Nollywood as a film industry is aiming to create a more professional atmosphere among its various actors and actresses. With very good performances exhibited by actors and actresses in Nollywood, the performing arts will develop and produce better films for viewers.

Nollywood as a film industry should always be involved in developing better actors and actresses who present top quality performances and can fit into film industries such as Hollywood and Bollywood. For instance, New African magazine (2012: p. 30) observed that "Charlize Theron is a South African actress who holds the honour of being the only African to win an Academy Award for best actress in 2003 film 'Monster' produced in Hollywood.”

\subsection{Influence of Nollywood Films on the Socio-Economic, Political and Cultural Aspect of Nigeria}

The freedom restricted to Nollywood at all levels have helped enrich the kind of programmes aired thereby showing various aspect of the Nigerian cultures. Nollywood has recreated films which reflect on the immensely rich culture of Nigeria. Films like Igodo, Atinga, Moremi, Eva (The Mystery River), Festival of Fire and The gods Are not To Blame are some Nollywood films that display our cultural prowess, values and norms.

Nollywood use of indigenous languages in her film production is another aspect of restoring our dynamic cultural values. Films produced in our indigenous Languages such as Igbo, Yoruba and an addition of Hausa, Efik, and Fulani has lured viewers among various ethnic climes. Such indigenous films include: Sango, Oranmiyan, Omo-Ode-de, Thunderbolt, Ori, Owo-Okuta Kulba-Na-Barna, Baban-Yaro, Shamsiya, Rattlesnake, and Jezebel.

Films that reflect on political struggles and corrupt politicians who use every possible way to either rig elections, or win elections are produced into films. Some films in the area of politics are: Who Will Kill the President, The President Must Hear This, Emergency, and Broad Day Light.

Some Nollywood Films directly or indirectly brings to mind the poor state of our rural settings; the neglects caused by undevelopment, the poor state or lack of social amenities which the government can in the long run pin point possible developmental needs in such areas where some Nollywood films are acted. 
Nollywood has also produced films showing the state of corruption, insecurity, and political violence, poor state of our health sector, injustice, family unity, reconciliation and communal harmony.

\subsection{Nollywood Films as a Tool for Development and Nation Building}

1) To build a dynamic platform where films in Nollywood will meet international standards in terms of competition, budgeting and audience (viewer) acceptance, films with local nuances or some nationalistic objectives should not be restricted in exhibition outside their area of origin.

2) Nollywood accords over 20,000 employee a year according to Pierre (2008: p. 13) in both skilled and artistic careers (script writers, producers, directors, cameramen, recording technicians, lighting engineers, film editors, music composers, sound effects experts, studio managers, art critics and other essential contributors) are already moving the effort of Nollywood film industry forward.

3) The Nigerian model offers undeniable assets; video is a part of films commercial lifespan in the following order; (theatre release, broadcast on free-paying television, on public television, on planes and in hotels). In South Africa video distribution doubles or triples films revenue. Video's success in Nigeria shows therefore that the potential to distribute film is profitable.

4) The future of films will flourish through films that explore social, developmental, economic and emotional issues, or films that evoke local cultural roots by updating legends among other areas that covers the nitty-gritty of the society.

5) Censorship: The well structuring of Nollywood films can be successful through the collective measures put in place by a very co-ordinated effort of regulatory bodies such as National Film and Video Censor Board (NFVCB), and National Copyrights Commissions (NCC).

\subsection{Challenges and Prospects of Nollywood Film Industry}

Nollywood film industry has come a long way through thick and thin. It remains the all-important platform for film making in Nigeria especially films done in the Eastern and Southern parts of Nigeria. However, in its effort to meet up with international film projections the industry keeps finding initiatives that will help Nollywood establish and build it's kind of brand films among the other film industries of the world (i.e. expectations, performances and outcomes).

One of the major challenges facing Nollywood is the fetish and occult styled films. Films bearing fetish acts and scenes became a thing of concern among so many film observers, who saw many Nollywood (themes), emerging on such line of production. In view of such Nollywood films in Kenya, Judy Kibinge (producer of Dangerous Affair) argues that "Nigerian videos presents a stereotypical view of West Africans and leaves Kenyans wondering whether their sole pre-occupation are love, witchcraft and money. According to the image portrayed in the films, Nigerians are controlled either by witchcraft or religion.”

ElombeSukari also spoke about the violent and occult nature of Nollywood films, but however, noted that not all scenes are full of diabolic, magic, fetishism and sorcery. Today Nollywood films have shattered grounds to other concerned activities that affect the society. The over use of fetishism was over popularized on film scenes such as Evil Genius, Igodo, Issakaba, The Power of Darkness, Blood Money, Billionaire Club, Rituals, Aye Owo and Posi Alaya (Yoruba films) such films gave many viewers in other parts of Africa and the world who watched Nollywood films concerns. However, issues about the economy, family values, and political wars are now changing and shaping Nollywood films.

Piracy: The dominant challenge faced by Nollywood is that of piracy. Piracy in Nollywood is seen as a bad omen that has eaten so deep into the activities of both Nollywood film industry and the entertainment sector. This singular factor of piracy by those reproducing other people efforts in the film industry is a thing of concern. Their actions have subverted the effort of producers and marketers as multiple and inferior copies of films are illegally reproduced and released out to Nigerians.

Funding: Without appropriate funds, film production becomes highly unsuccessful. This is to say that film production is highly capital intensive. An average production in Nollywood could cost $\$ 12.000$ to 15.000 as against Hollywood blockbusters which funding could range from ten million dollars or more.

With government and the private sector industries playing a clear cut role in the area of funding, Nollywood film industry can reach its optimum potentials and thereby achieves its aim and objectives by equally competing with what is obtainable in Hollywood and Bollywood in terms of quality, graphics and level of production. 
Inadequate Training: Training is very essential in the film industry. Artistes, producers, directors and other stakeholders need to improve their skills through constant training. It is foolhardy for a producer who claims to have produced five films to think he or she has known the all there is to be known in the art.

Unprofessionalism: Another plague besetting film and movie production in Nigeria is lack of professionalism. This is closely tied to training. For Nollywood to move further the industry needs to have an in-depth drive for success which needs to be employed by all concerned in the industry.

Quality Control: Quality control is another challenge faced in Nollywood film industry. For a sector that is the third largest in the world, most of its films are said to be poorly and mass produced. Pierre (2008: p. 13) observed that, "Nollywood makes approximately 1500 films a year which results in very low quality content". The duration of film production which takes 10 to 12 days is another serious area that needs to be considered.

\section{Prospects in Nollywood Film Industry}

The prospects in Nollywood film industry are enormous. These are a result of the film industry show casing issues of necessities on both positive and negative happenings in the country. As such, individuals abound with talents, creative ideas; abilities and the need to create a niche for themselves are giving the needed opportunities to become better actors and actresses as noted from the present crop of film casts in the industry.

Technology as a component of development is changing the art of film making in the respective film industries of the world. Today films are considered to transcend some forms of development in the society. Through the infusion of technology into films, new ideas are developed and used in making better films for the society.

The levels of films produced at present in Nollywood are striving for improved casting, scripting, location, graphics and production designs. These efforts indicate that Nollywood industry is trying to improve in the area of film productions. Today films produced by Nollywood take an enriched outlook in terms of cast, scenes, welfare, visual effects and other production aspects.

\subsection{Conclusions}

The audience, who are ardent viewers of films, produced by Nollywood and other film industries such as Bollywood and Hollywood amongst others film industries sees and reacts to the different qualities and performances of the various actors and actresses that cut across the various film industries.

Viewers however, consider the level of production and funding put into the production as an integral part of film production quality. Viewers therefore believe that Nollywood has already come of age, and as such should also put more efforts into the production of films and artistic performances.

However, the peculiar problems which keep presenting themselves in Nollywood are artistic qualities, poor scripting, poor scene design, production and casts performance. It is therefore of great importance, that the film industry called Nollywood continues to search for solutions on the problems facing the film industry through workshops, premiers, film festivals and film seminars. These efforts, if given the necessary impetus, will aid the production and artistic qualities of films in Nollywood.

Nollywood's efforts in film production in Nigeria which is called home videos should be applauded for its pivotal role and contribution in the entertainment sector. Today Nollywood has played a part in alluring viewers on a global platform through the availability of pay-viewing on satellite television channels, cinema viewership and CD/DVD purchases which has seen the film industry as one of the fast growing, most exciting, most dynamic and business oriented platform in the world when it comes to film production.

For Nollywood to be termed completely successful, its global reach needs to improve and Nigerians and the Africans continent has to see Nollywood living off the shadows of Hollywood and Bollywood in terms of films with same title and same production patterns.

Nollywood however has written a success in Africa which other African countries are trying within their line of production to attain. The success story of Nollywood today has envisioned the years ahead in Nigerians film industry as better things yet to come.

\subsection{Recommendations}

For Nollywood to improve and meet up to contemporary aspects of modern day film production, the necessary actors, film makers and regulatory agencies, marketers, stakeholders, cinemas halls, day-viewing channels and 
distributors need to find possible and clear cut ways of meeting the present standard of film production obtainable on the international scenes.

1) Actors and actresses should at all times seek the available ideas for creativity through films workshops, seminars, films festivals, such as Pan Africa Film and Television Festival of Ouagadougou, International Film Festival (IFF), Asia-Pacific Film Festival (APFF), Castle Rock Film Festival, British Academy of Film and Television Arts (BAFTA), International Cinema Festival of India (ICFI), European Film Festival (EFF), Berlin International Film Festival. Some in Nigeria include; Africa International Film Festival (AIFF), Abuja International Film Festival, Lagos International Film Festival and Festival of Indigenous African Language Films. These areas of collective and shared experiences will help improve upon how films are done in Nollywood.

2) Reducing the rate of borrowed ideas found in Nollywood's storylines, directing and film interpretation will enhance its credibility. This will give Nollywood a, sense of direction to seek ways of tapping more from the social, cultural, political and economic situations which are prevalent in the nation.

3) The roles and functions of National Film and Video Censors Board (NFVCB) and National Film Cooperation (NFC) should be clearly stated and obtained for Nollywood to brace up to its challenges on areas of themes production and level of technology which is lacking on a high level.

4) A standard that will safeguard Nollywood films getting pirated should be made available by making marketing and distribution standard very coordinated.

5) To ensure that films produced are registered with their code numbers before they are released daily into circulation.

6) The film industry can gain professionally if film academies created for practical acting and other related aspects of film production are upgraded to meet international standard. For instance, National Film Institute located in Jos Plateau State in Nigeria.

7) Funding should be made available by concerned stakeholders because through funding Nollywood can live and meet up to Hollywood and Bollywood levels of production.

\section{References}

Asobele, T. (2003). Nigeria Diplomacy in 20th Centuary. Lagos, Lagos State: Upper Standard Press.

Christopher, E. (2008). Film/Cinema Development: From Still to Motion Picture. In R. M’Bayo, \& O. Olufemi (Ed.), Emergence, Growth and Challenges of Films and Home Videos in Nigeria (pp. 19-52). Maryland: African Renaissance Books Incorporated.

Felix, O., \& Cecilia, O. (2008). The Relevance of Home Video Themes to the Nigerian Society. In R. M’Bayo Olufemi Onabajo (Ed.), Emergence, Growth and Challenges of Films and Home Videos in Nigeria (pp. 120-128). Maryland: African Renaissance Books Incorporated.

Lenin, V. I. (1958). Collected Works. Prague: SPNL.

New African Magazine (2012). The 100 most Influential Africans (p. 30).

Oladunjoye, T. (2008). Jumping on the Bandwagon in Nollywood. In B. Pierre (Ed.), The Video Phenomenon in Nigeria (pp. 32-39). London: James Curry.

Opubor, E. A. et al. (1979). The Status, Role and Future of the Film Industry in Nigeria. In E. A. Opubor, \& E. N. Onura (Eds.), The Development and Growth of the Film industry in Nigeria (pp. 1-8). Lagos: Third International Press.

Pierre, B. (2008). The Italian of Africa. In B. Pierre (Ed.), The Video Phenomenon in Nigeria (pp. 13-21). London: James Curry.

Pierre, B. (2008). Audacity, Scandal and Censorship. In B. Pierre (Ed.), The Video Phenomenon in Nigeria (pp. 43-51). London: Published by James Curry.

M’Bayo, R., \& Olufemi, O. (2008). Emergence, Growth and Challenges of Films and Home Videos in Nigeria. USA: African Renaissance Books Incorporated.

Segun, O, (2008). Nollywood, Bollywood, Hollywood: The Impact of Modern Technology on Production. In R. M’Bayo, \& O. Olufemi (Eds.), Emergence, Growth and Challenges of Films and Home Videos in Nigeria (pp. 301-308). Maryland: African Renaissance Books Incorporated.

Udomisor, I. W. et al. (2012). Content Analysis of Programs Produced by Nollywood Particularly on Africa Magic: DSTV. Research on Humanities and Social Sciences, 2, 27-34. www.nollywoowmovies.com 